\title{
Bacteriocin-encoding genes and ExPEC virulence determinants are associated in human fecal Escherichia coli strains
}

\author{
Lenka Micenková', Barbora Štaudová', Juraj Bosák1, Lenka Mikalová1, Simona Littnerová², Martin Vrba,
} Alena Ševčíková ${ }^{3}$, Vladana Woznicová ${ }^{4}$ and David Šmajs ${ }^{1^{*}}$

\begin{abstract}
Background: A set of 1181 E. coli strains of human fecal origin isolated in the South Moravia region of the Czech Republic was collected during the years 2007-2010. Altogether, 17 virulence determinants and 31 bacteriocinencoding genes were tested in each of them.

Results: The occurrence of bacteriocin-encoding genes was found to be positively correlated with the occurrence of $E$. coli virulence factors. Based on the presence of virulence factors and their combinations, $E$. coli strains were classified as non-pathogenic E. coli $(n=399)$, diarrhea-associated E. coli $(n=179)$ and ExPEC strains $(n=603)$.

Non-pathogenic and diarrhea-associated E. coli strains had a low frequency of bacteriocinogeny (32.6\% and 36.9\%, respectively). ExPEC strains encoding S-fimbriae (sfa), P-fimbriae (pap) and having genes for aerobactin biosynthesis (aer, iucC), a-hemolysis ( $a-h l y)$ and cytotoxic necrosis factor (cnf1) were often bacteriocinogenic (73.8\%), had a high prevalence of bacteriocin multi-producers and showed a higher frequency of genes encoding microcins H47, M, V, B17 and colicins E1, la and S4.

Conclusions: The occurrence of bacteriocin-encoding genes and EXPEC virulence determinants correlate positively in E. coli strains of human fecal origin. Bacteriocin synthesis appears to modulate the ability of E. coli strains to reside in the human intestine and/or the virulence of the corresponding strains.
\end{abstract}

Keywords: Escherichia coli, Colicin, Microcin, Bacteriocin, Virulence factor

\section{Background}

The endogenous human gut microbiome has several important functions including nourishment, the training of innate immunity and the regulation of epithelial development [1]. Although the Escherichia coli population represents a rather small portion of the intestinal bacterial microflora, E. coli nonetheless occupy an important niche with regard to their close proximity to intestinal epithelium, wherein they utilize available oxygen and facilitate anaerobic growth [2]. Intestinal microflora also prevent the growth of pathogenic bacteria, either by competing for nutrient sources, or through

\footnotetext{
* Correspondence: dsmajs@med.muni.cz

'Department of Biology, Faculty of Medicine, Masaryk University, Kamenice 5, Building A6, Brno 625 00, Czech Republic

Full list of author information is available at the end of the article
}

direct bacterial antagonism mediated by bacteriocins and bacteriophages [3].

E. coli is a highly diverse species with respect to its gene content, phenotype and virulence [4]. Based on different virulence factors, $E$. coli strains can be classified into three main groups: commensal, intestinal pathogenic and extraintestinal pathogenic E. coli (ExPEC) [5]. Commensal strains are commonly considered to be nonpathogenic. It has been shown that intestinal and extraintestinal pathogenic E. coli strains can develop from commensal strains by acquisition of virulence factors $[6,7]$.

Intestinal pathogenic (diarrhea-associated) E. coli is a typical mucosal pathogen which uses different pathogenic strategies including invasion of host cells (enteroinvasive E. coli, EIEC), production of enterotoxins (enterotoxigenic E. coli, ETEC) and production of Shiga- 
like toxins (enterohemorrhagic E. coli, EHEC) [8]. Enteropathogenic E. coli (EPEC) strains cause attachingand-effacing (A/E) lesions and harbor the EAF plasmid [8]. Diffuse-adherent strains of E. coli (DAEC) are characterized by continuous adherence to eukaryotic cells mediated by afimbrial adhesins [9], while enteroaggregative (EAggEC) strains produce an aggregative adherence (AA) pattern [10] when adhering to HEp-2 cells.

ExPEC strains carry different combinations of virulence factors. Johnson et al. (2003) defined ExPEC strains as those possessing 2 or more of the following virulence factors: $\mathrm{P}$ fimbriae, S/F1C fimbriae subunits, Dr-antigen binding adhesins, aerobactin receptor and group 2 capsule synthesis [11].

Another important characteristic of human E. coli strains is production of bacteriocins. Colicins and microcins are antimicrobial agents with a relatively narrow spectrum of activity [12-14]. In general, microcins are known to have a wider spectra of antibacterial activity compared to colicins $[14,15]$. Colicin Js $[16,17]$ is unique in that it shares features of both colicins and microcins. The ecological role and molecular evolution of bacteriocinogeny are less clear but synthesis of bacteriocins may have both invasive and defensive functions in microbial communities [18]. Bacteriocin production is a common feature of many probiotic bacteria. For example, microcins $\mathrm{H} 47$ and $\mathrm{M}$ are active substances produced by the non-pathogenic, probiotic E. coli strain Nissle 1917 [19].

At the same time, several studies have shown an association between the production of some types of bacteriocins and pathogenic E. coli strains [20-23]. Previous studies have found that genes encoding colicin E1, as well as microcins H47, M, I47, E492 and V were associated with extraintestinal pathogenic $E$. coli strains [20-23]. Colicin E1 is also known to have toxic effects on eukaryotic cells and is considered to be a virulence factor in UPEC strains $[21,24,25]$. Microcins H47 and M are induced when iron is a limiting factor and are associated with competition for iron [22,26]. Synthesis of microcin $\mathrm{H} 47$ and $\mathrm{M}$ could therefore be advantageous in bacteremia of urinary tract origin $[22,26]$.

Previously published studies have only provided partial insight into the association between bacteriocin production and bacterial virulence, as they were primarily focused upon UPEC strains and differed in the number of detected bacteriocin and virulence genes. Azpiroz et al. (2009) screened 5 microcin types in 125 UPEC strains and 9 virulence factors [20], while Budič et al. (2011) and Petkovšek et al. (2012) analyzed 14 virulence factors (primarily those associated with urinary tract infections) and 19 bacteriocin types in 105 UPEC strains [22,23]. Similarly, Abraham et al. (2012) analyzed 16 bacteriocin types and 18 virulence factors in a collection of 159
UPEC strains [27]. Together, these studies identified an association between microcins ( $\mathrm{M}, \mathrm{H} 47, \mathrm{~V}, \mathrm{~B} 17$ and L) and several virulence genes [20,22,23,27]. Studies by Gordon et al. (2005) and Gordon and O'Brien (2006) focused on 266 fecal $E$. coli strains and identified an association between strains encoding at least one microcin type, and four genes involved in iron acquisition (from a total of 29 tested virulence determinants) [26,28].

The main aim of our study was to test the association between bacteriocin production and bacterial virulence within a large collection of $E$. coli strains $(\mathrm{n}=1181)$ isolated from human gut microflora. In this study, new associations between bacteriocin-encoding genes and virulence determinants were found in human fecal E. coli strains.

\section{Results}

Detection of virulence determinants and bacteriocinencoding genes

Altogether, 18 DNA determinants (pCVD432, $\alpha$-hly, afaI, aer, cnf1, sfa, pap, ial, lt, st, bfpA, eaeA, ipaH, iucC, $\operatorname{fim} A$ and stx 1, stx 2 and ehly) encoding 17 different virulence factors were tested in each of $1181 \mathrm{E}$. coli strains (Additional file 1: Table S1). The vast majority of strains (94.7\%) possessed at least one virulence factor. The most common virulence determinant was the fimA gene (encoding fimbriae type I), which was detected in $87.9 \%$ of all strains.

Genes encoding 29 bacteriocin types including 24 colicin types (A, B, D, E1-9, Ia, Ib, Js, K, L, M, N, S4, U, Y, 5 and 10 ) and 5 microcin types (B17, C7, J25, L and V) were tested in each of $642 \mathrm{E}$. coli bacteriocin producer strains. Further, the prevalence of chloroform sensitive microcins H47 and M [19] was tested in each of the 1181 E. coli strains. The average prevalence of bacteriocinogeny in the set of 1181 E. coli strains was $54.4 \%$ (Additional file 1: Table S1). In contrast to other bacteriocin determinants, genes encoding colicins A, E4, E9 and $\mathrm{L}$ were not detected in any producer strain. Most of bacteriocin producers were strains producing two or more bacteriocin types (Additional file 1: Table S1).

\section{Association between bacteriocin and virulence determinants}

We found that $28.6 \%$ of $E$. coli strains possessing no virulence determinant $(n=63)$ produced bacteriocins and $34 \%$ of the strains harboring one virulence determinant $(\mathrm{n}=377)$ produced bacteriocins. In addition, $58.2 \%$ of $E$. coli encoding two virulence determinants $(\mathrm{n}=220)$ had bacteriocin genes and $70.6 \%$ of the strains with 3 to 7 virulence determinants $(n=521)$ were bacteriocinogenic (Figure 1).

A correspondence analysis (CA) was performed using individual virulence determinants and bacteriocin- 


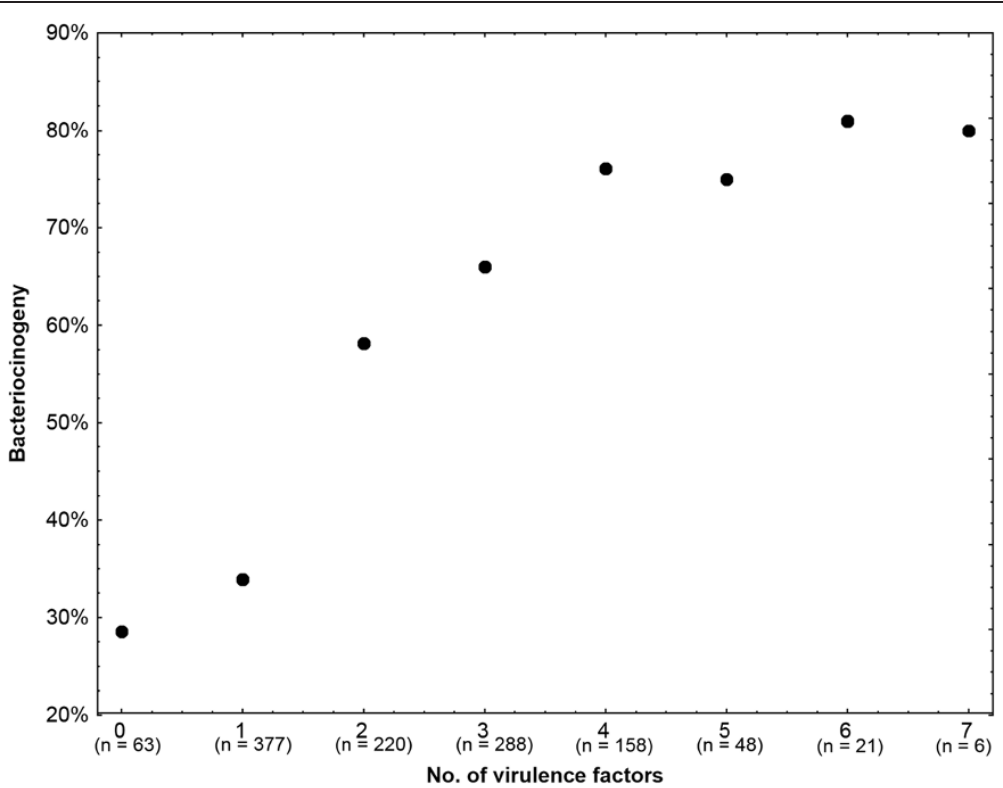

Figure 1 Association between number of virulence factors encoded by $E$. coli strains and bacteriocin production. Frequency of bacteriocinogeny in $E$. coli strains correlates with number of virulence factors coded by $E$. coli. The $x$ axis represents the number of virulence factors coded by $E$. coli strains ( $n$ represents the number of strains encoding the appropriate number of virulence factors) and the $y$ axis shows the frequency of bacteriocinogeny.

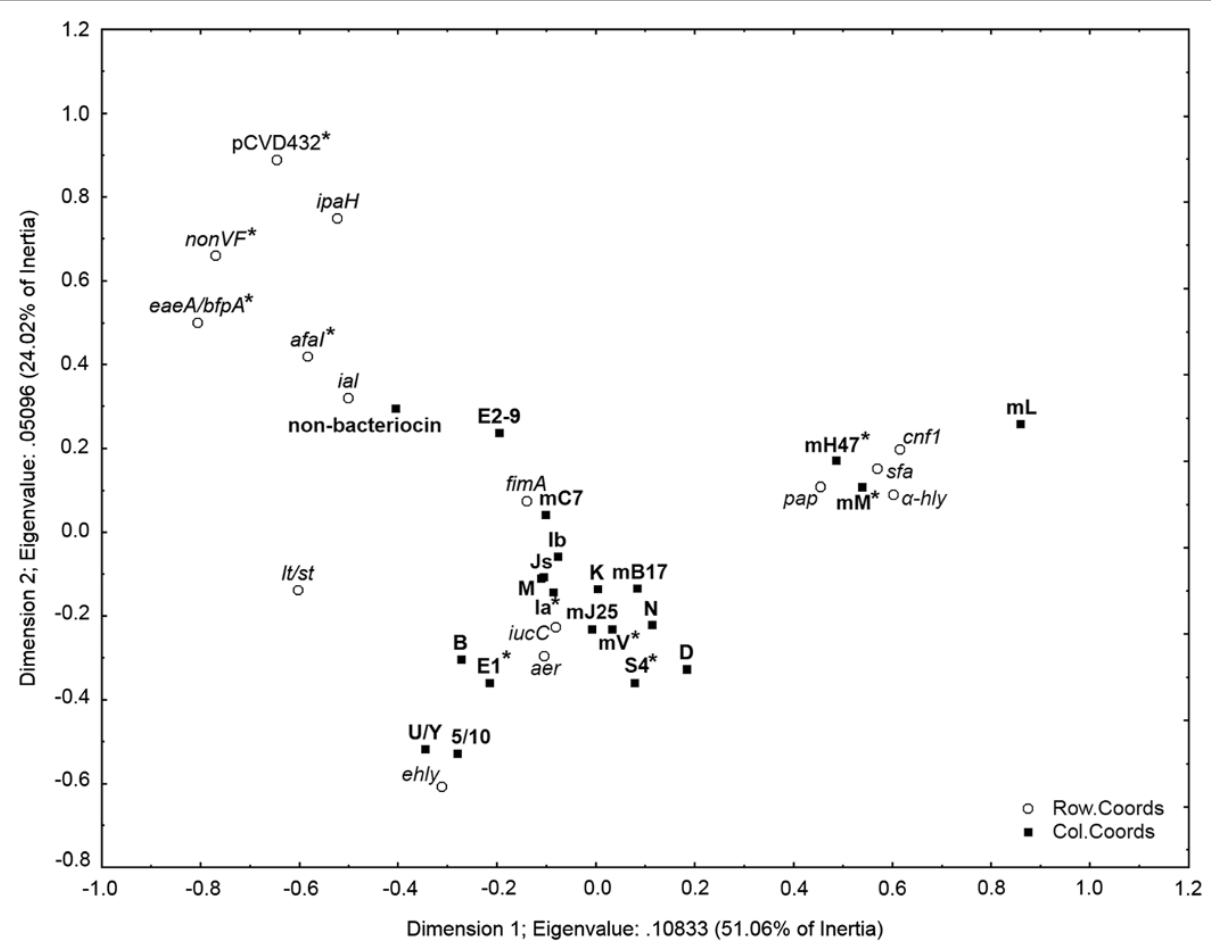

Figure 2 Correspondence analysis for bacteriocin types and virulence factors. Association between virulence factors ( $a-h l y$, afal, aer, cnfl, sfa, pap, pCVD432, ial, It, st, bfpA, eaeA, ipaH, iucC, fimA, ehly) and bacteriocin types (B, D, E1, E2-9, la, lb, Js, K, M, N, S4, U/Y, 5/10, mB17, mC7, $\mathrm{mH} 47, \mathrm{~mJ} 25, \mathrm{~mL}, \mathrm{mM}$ and $\mathrm{mV}$ ) in $1181 \mathrm{E}$. coli strains. The $\mathrm{x}$ axis accounted for $51.06 \%$ of total inertia and the $y$ axis for $24.02 \%$. Please note the close association between virulence determinants pap, sfa, cnfl and $a$-hly and genes for microcins H47, M and L. Genes encoding aerobactin synthesis plotted close to bacteriocin genes encoding microcins J25, V and B17 and colicins B, E1, 5/10, Ia, Ib, Js, M, K, N, S4 and D. Fisher's exact test was used to analyze the degree of association among bacteriocin types and virulence factors; statistically significant results for different virulence factors and bacteriocin types are indicated by asterisks ( $a-h l y, c n f 1, s f a, p a p-\mathrm{mH} 47$ and mM; iucC, aer - E1, la, S4 and mV; afal, eaeAlbfpA, pCVD432, nonVF - bacteriocin non-producers). 
encoding genes (Figure 2). In addition to this twodimensional representation, Fisher's exact test was used to analyze the association between bacteriocin types and virulence determinants. Genes encoding aerobactin synthesis were $(a e r, i u c C)$ were significantly associated with genes for microcin $\mathrm{V}(\mathrm{p}<0.01)$ and with genes encoding colicins E1 ( $\mathrm{p}<0.01)$, Ia $(\mathrm{p}<0.01)$ and S4 $(\mathrm{p}=0.01)$. The $\alpha$-hly, cnf1, sfa and pap virulence determinants were plotted together and were associated with genes for microcins H47 $(\mathrm{p}<0.01)$ and $\mathrm{M}(\mathrm{p}<0.01)$. Bacteriocin non-producers were associated with afaI $(\mathrm{p}<0.01)$, eaeA/bfpA $(\mathrm{p}<0.01), \mathrm{pCVD} 432 \quad(\mathrm{p}=0.03)$ and with strains in which virulence determinants were not detected $(\mathrm{p}<0.01)$ (Figure 2).

\section{Association between bacteriocin-encoding genes and $E$. coli pathotypes}

Based on the presence of virulence factors, $E$. coli strains were divided into three groups: (1) non-pathogenic (commensal, non enterovirulent, nonEVEC) E. coli ( $\mathrm{n}=$ 399), (2) diarrhea-associated E. coli (EAggEC, ETEC, EIEC, EPEC and DAEC; $\mathrm{n}=179$ ) and (3) fecal E. coli with characteristics similar to ExPEC, denoted ExPEC in this study $(\mathrm{n}=603)$ (Table 1). Non-pathogenic E. coli were defined as those with no detected genes for virulence factors or those that only had the gene for fimbriae type I (fimA gene). Diarrhea-associated E. coli strains encoded virulence factors typical for each of the diarrhea-associated pathotypes including EAggEC (pCVD432), ETEC (lt/st), EIEC (ial/ipaH), EPEC (eaeA/ $b f p A)$, EHEC (stx1/stx2/ehly) and DAEC (afaI) strains. All other strains containing genes for different virulence factors (e.g. $\alpha$-hemolysin, P-fimbriae, S-fimbriae, cytotoxic necrosis factor, aerobactin synthesis) and combinations thereof were classified as ExPEC. The results of the correspondence analysis of individual virulence determinants and bacteriocin genes (Figure 2) showed that a majority of bacteriocin genes overlap with virulence determinants belonging to ExPEC strains.

The occurrence of bacteriocinogeny (i.e. occurrence of at least one bacteriocin-encoding gene) in nonEVEC strains (32.6\%) and in diarrhea-associated E. coli strains (36.9\%) was significantly lower than among ExPEC (73.8\%; $\mathrm{p}<0.01)$ (Table 2). In addition, a similar frequency of bacteriocin types was also found in both groups of nonEVEC and diarrhea-associated E. coli. Among nonEVEC strains, those with a single bacteriocin gene were most common, while ExPEC strains more

Table 1 Occurrence of virulence factors in $E$. coli pathotypes

\begin{tabular}{|c|c|c|c|c|}
\hline \multicolumn{2}{|l|}{ Virulence factors } & \multicolumn{3}{|c|}{ Pathotype } \\
\hline & & \multirow{2}{*}{$\begin{array}{l}\text { Non-pathogenic E. coli* } \\
\mathrm{n}=399(\%)\end{array}$} & $\begin{array}{l}\text { Diarrhea-associated } E . \text { coli }^{* *} \\
\mathrm{n}=179(\%)\end{array}$ & \multirow{2}{*}{$\begin{array}{l}\text { ExPEC*** } \\
n=603(\%)\end{array}$} \\
\hline & & & & \\
\hline Aggregative adherence plasmid & pCVD432 & - & $13(7.3)$ & - \\
\hline Invasive associated locus & ial & - & $44(24.6)$ & - \\
\hline Heat-stable enterotoxin & st & - & $8(4.5)$ & - \\
\hline Heat-labile enterotoxin & It & - & $7(3.9)$ & - \\
\hline Intimin & eaeA & - & $26(14.5)$ & - \\
\hline Bundle-forming fimbriae & $b f p A$ & - & $1(0.6)$ & - \\
\hline Invasion plasmid H & ipaH & - & 19 (10.6) & - \\
\hline Aerobactin synthesis & aer & - & $68(38.0)$ & $342(56.7)$ \\
\hline Fimbriae type 1 & $\operatorname{fim} A$ & $336(84.2)$ & $149(83.2)$ & $553(91.7)$ \\
\hline a-hemolysin & a-hly & - & $3(1.7)$ & $88(14.6)$ \\
\hline Afimbrial adhesin & afal & - & $78(43.6)$ & - \\
\hline Aerobactin synthesis & incC & - & $80(44.7)$ & $396(65.7)$ \\
\hline Cytotoxic necrotizing factor & cnf1 & - & $1(0.6)$ & $43(7.1)$ \\
\hline S-fimbriae & sfa & - & $6(3.4)$ & 227 (37.6) \\
\hline P-fimbriae & pap & - & 19 (10.6) & $201(33.3)$ \\
\hline Shiga-toxin 1 & stx 1 & - & - & - \\
\hline Shiga-toxin 2 & $s t \times 2$ & - & - & - \\
\hline Enterohemolysin & ehly & - & $9(5.0)$ & - \\
\hline
\end{tabular}

${ }^{*}$ E. coli strains with no detected genes for virulence factors or those possessing only gene for fimbriae type I (fimA gene).

**EAggEC - pCVD432 (aggregative adherence plasmid); ETEC - It/st (heat-labile and heat-stable enterotoxin); EIEC - ial/ipaH (invasion associated locus/invasion plasmid H); EPEC - bfpA/eaeA (bundle-forming fimbriae/intimin); EHEC (stx1/stx2/ehly); DAEC - afal (afimbrial adhesin I).

${ }^{* * *} E$. coli strains which contain different virulence factors (except those that are typical for previously described diarrhea-associated $E$. coli) typical for extraintestinal E. coli strains (a-hemolysin, P-fimbriae, S-fimbriae, cytotoxic necrosis factor, aerobactin synthesis). 
Table 2 Occurrence of bacteriocinogeny and bacteriocin types among $E$. coli strains

\begin{tabular}{|c|c|c|c|c|c|c|}
\hline \multirow[t]{2}{*}{ Bacteriocinogeny } & \multicolumn{3}{|c|}{ Pathotype } & \multicolumn{3}{|c|}{ Statistics* } \\
\hline & $\begin{array}{l}\text { 1. Non-pathogenic } E \text {. coli } \\
\mathrm{n}=399(\%)\end{array}$ & $\begin{array}{l}\text { 2. Diarrhea-associated } E \text {. coli } \\
n=179(\%)\end{array}$ & $\begin{array}{l}\text { 3. ExPEC } \\
n=603(\%)\end{array}$ & $\begin{array}{l}1 \times 2 \\
p\end{array}$ & $\begin{array}{l}1 \times 3 \\
p\end{array}$ & $\begin{array}{l}2 \times 3 \\
p\end{array}$ \\
\hline Bacteriocinogenic strains & $130(32.6)$ & $66(36.9)$ & $445(73.8)$ & $--^{* *}$ & $<0.01$ & $<0.01$ \\
\hline \multicolumn{7}{|l|}{ Bacteriocin types } \\
\hline $\mathrm{mV}$ & $18(4.5)$ & $18(10.1)$ & $152(25.2)$ & 0.04 & $<0.01$ & $<0.01$ \\
\hline $\mathrm{mM}$ & $17(4.3)$ & $7(3.9)$ & $123(20.4)$ & - & $<0.01$ & $<0.01$ \\
\hline $\mathrm{mH} 47$ & $28(7.0)$ & $14(7.8)$ & $165(27.4)$ & - & $<0.01$ & $<0.01$ \\
\hline mB17 & $10(2.5)$ & $8(4.5)$ & $57(9.5)$ & - & $<0.01$ & - \\
\hline la & $53(13.3)$ & $23(12.8)$ & $125(20.7)$ & - & $<0.01$ & - \\
\hline E1 & $19(4.8)$ & $15(8.4)$ & $94(15.6)$ & - & $<0.01$ & 0.04 \\
\hline S4 & - & - & $11(1.8)$ & - & 0.01 & - \\
\hline \multicolumn{7}{|l|}{ Bacteriocin producer strains } \\
\hline Mono-producers*** & $63(48.5)$ & $23(34.8)$ & $141(31.7)$ & - & $<0.01$ & - \\
\hline la & $23(17.7)$ & $3(4.5)$ & $18(4.0)$ & 0.04 & $<0.01$ & - \\
\hline Double-producers**** & $44(33.8)$ & $25(37.9)$ & $161(36.2)$ & - & - & - \\
\hline $\mathrm{mH} 47, \mathrm{mM}$ & $5(3.8)$ & $4(6.1)$ & $50(11.2)$ & - & 0.03 & - \\
\hline Multi-producers***** & $21(16.2)$ & $15(22.7)$ & 139 (31.2) & - & $<0.01$ & - \\
\hline
\end{tabular}

*Fisher's exact test with Bonferroni correction.

**not statistically significant.

****oducers of one bacteriocin type.

****producers of two bacteriocin types.

*****producers of three and more bacteriocin types.

often contained several bacteriocin genes in a single strain. Compared to nonEVEC and diarrhea-associated strains, ExPEC had higher frequencies of genes encoding microcins $\mathrm{V}, \mathrm{H} 47, \mathrm{M}(\mathrm{p}<0.01$ against both nonEVEC and diarrhea-associated strains) and gene encoding colicin E1 $(\mathrm{p}<0.01$ against nonEVEC, $\mathrm{p}=0.04$ against diarrhea-associated strains). In addition, compared to nonEVEC strains, ExPEC had higher frequencies of genes encoding microcin B17 (9.5\%; $<<0.01)$ and colicins Ia $(20.7 \% ; \mathrm{p}<0.01)$, E1 (15.6\%; p < 0.01) and S4 $(1.8 \%$; $\mathrm{p}=0.01)$.

\section{Discussion}

In this study, the average prevalence of bacteriocinogenic E. coli strains isolated from fecal microflora was $54.4 \%$. This value is close to the upper range limit seen in previous studies, where the prevalence of bacteriocinogenic $E$. coli strains varied from 25 to $55 \%$ $[15,21,26,27,29-31]$. However, these studies differed in a number of important ways including cultivation conditions and indicator bacteria used for detection of bacteriocin production and/or in the number of detected bacteriocin genes. Older studies on the prevalence of bacteriocinogeny in fecal E. coli strains only focused on the identification of colicin production [30,32]. While Šmarda and Obdržálek (2001) used five different indicator strains to detect colicin production in the fecal $E$. coli strain 1043 [32], Achtman et al. (1983) used 2 indicator strains for the detection of colicin producers in a sample of 234 fecal E. coli strains [30]. More recently, Gordon and O'Brien (2006) used PCR with 19 bacteriocin genes to screen 266 fecal E. coli strains (38\% of which were bacteriocinogenic) [26], and Šmajs et al. (2010) detected 29 bacteriocin types in 411 fecal E. coli strains (55\% of which were bacteriocin-encoding strains) [21].

Our results have revealed that the frequency of bacteriocinogeny in $E$. coli strains positively correlates with the detected number of virulence determinants. Bacteriocinogeny increased by as much as $75-80 \%$ depending on the number of encoded virulence factors. To our knowledge, this is the first time that the correlation between bacteriocinogeny frequency and the number of encoded virulence factors has been shown. This finding suggests that at least some bacteriocin-encoding genes should be considered as factors which increase the virulence of E. coli strains.

E. coli strains encoding only fimbriae type I did not show differences in the frequency of bacteriocinogeny compared to strains without genes for virulence factors. The role of fimbriae type I in development of human infections is not clear. Although deletion of the fim gene cluster from virulent $E$. coli strain $\mathrm{O} 1: \mathrm{K} 1: \mathrm{H} 7$ attenuated virulence in the urinary tract infection (UTI) model [33]; 
possession of fimbriae type 1 in E. coli strains from different sources was not found to correlate with the ability to cause UTIs [34-39]. Several virulence factors, typical for diarrhea-associated E. coli strains, including pCVD432 (EAggEC), ial/ipaH (EIEC), eaeA/bfpA (EPEC) and afaI (DAEC) were not found to be associated with bacteriocin genes. Bacteriocin producers therefore appear to be mainly associated with ExPEC virulence factors (E. coli strains containing combinations of sfa, pap, aer, iucC, cnf1, $\alpha$-hly determinants). The occurrence of these virulence factors were associated with both chromosomally (microcins $\mathrm{H} 47$ and M) and plasmid encoded colicin (E1, Ia and S4) and microcin types $(\mathrm{B} 17, \mathrm{~V})$.

Presently, several bacteriocins including colicin E1, and microcins H47, I47, E492, M, and V are considered virulence factors in extraintestinal pathogenic $E$. coli strains [20-23]. Azpiroz et al. [20] and Budič et al. [22] found an association between production of microcins $\mathrm{H} 47$, I47, E492, M, and V and the distribution of virulence factors (i.e. hlyA, chf1, usp, iroN, iroCD, fyuA, papC, papG and $t c p C$ ) in uropathogenic strains of $E$. coli; from these results they assumed that production of these bacteriocin types could contribute to development of bacteraemia. Although different sets of virulence determinants and bacteriocin genes were used in these studies, our findings match with these observations.

We also found these associations between bacteriocin production and ExPEC virulence determinants among human fecal E. coli isolates. Moreover, we have found new associations between 3 bacteriocin types (microcin B17, colicins Ia and S4) and the ExPEC virulence characteristics of human fecal $E$. coli strains. Given that colicin Ia and microcin B17 are known to be encoded on relatively large plasmids, it is possible that the association with more virulent strains is due to other genes being harbored on these plasmids, and not by colicin synthesis itself. However, colicin S4 was found to be encoded on a small plasmid (7.4 kb) [40] that was similar to the colicin E1-encoding plasmid (6 kb) [21]. Since these small plasmids do not encode virulence factors, colicin S4 appears to be a potentially important virulence factor and/or an important factor of resident $E$. coli strains.

The presence of virulence determinants (e.g. genes encoding P-fimbriae, siderophore aerobactin, hemolysin and expression of $\mathrm{O}$ antigens, which are typical for ExPEC strains; and capsular types $\mathrm{K} 1$ and $\mathrm{K} 5$ ) are associated with resident $E$. coli strains [41-44]. At the same time, ExPEC strains causing extraintestinal infections like urinary tract infections and sepsis/meningitidis are believed to originate from the gut microflora. Their virulence determinants including adhesins (P-fimbriae, $\mathrm{S}$-fimbriae), toxins (e.g. hemolysin, cytotoxic necrotizing factor) and siderophores (e.g. aerobactin) appear to be important for E. coli strains to survive in the extraintestinal environment [45-47].

On the other hand, we found that diarrhea-associated strains from our set of 1181 fecal E. coli had a lower prevalence of bacteriocinogeny and a lower frequency of several bacteriocin producers. In addition, no specific bacteriocin types appear to be associated with virulence determinants that are typical for these strains. Unlike fecal strains which have the characteristics of ExPEC strains, diarrhea-associated strains are not considered to be resident human $E$. coli strains, which may explain the lower prevalence of bacteriocin genes.

In summary, bacteriocin synthesis is linked to strains with ExPEC characteristics and appears to increase the ability of $E$. coli to reside in the human gut. Moreover, at least several bacteriocin-encoding genes should be also considered as factors which increase the virulence of ExPEC strains.

\section{Conclusions}

The frequency of bacteriocin-encoding genes was found to be positively correlated with the frequency of $E$. coli virulence determinants. E. coli with virulence characteristics of ExPEC strains, i.e. strains encoding virulence factors S-fimbriae $(s f a)$, P-fimbriae (pap), cytotoxic necrosis factor (cnf1), $\alpha$-hemolysin $(\alpha-h l y)$ and aerobactin biosynthesis (aer, iucC) were more often found to harbor genes encoding synthesis of microcins (H47, M, V and B17) and colicins (E1, Ia and S4) than other tested E. coli strains.

\section{Methods}

\section{Bacterial strains}

E. coli strains were isolated from the intestinal microflora of 1181 patients living in South Moravia, Czech Republic. A set of 183 E. coli strains was isolated at St. Anne's University Hospital, Brno, CZ, and 998 E. coli strains at the University Hospital, Brno, CZ. E. coli strains were isolated between July 2007 and April 2010. 565 E. coli strains were isolated from female patients and 616 E. coli strains from males. All clinical samples were collected after patients gave informed consent. For children under the age of 18 , consent was obtained from parents. The study was approved by the ethics committee of the Faculty of Medicine, Masaryk University, Brno, CZ. A single isolate of $E$. coli was collected from each patient. Testing with ENTEROtest16 (Erba Lachema, Czech Republic) was used for bacterial identification. Indicator strains used for screening of bacteriocin production and the control bacteriocin producers used for PCR detection of bacteriocin genes, were previously described in detail [21]. 


\section{Screening of bacteriocin production}

Bacteriocin production was detected using the method described by Šmajs et al. (2010) [21]. Briefly, each of $1181 \mathrm{E}$. coli strains were simultaneously cultivated $\left(37^{\circ} \mathrm{C}\right.$ for 48 hours) in parallel on four different agar plates containing (i) TY (Trypton-yeast) agar (HiMedia, Mumbai, India) $\left(1.5 \%, \mathrm{w} / \mathrm{v}\right.$, solid agar), (ii) Difco ${ }^{\mathrm{Tm}}$ Nutrient broth (Difco Laboratories, Sparks, MD, USA), (iii) TY agar supplemented with mitomycin C, and (iv) TY agar supplemented with trypsin. Macrocolonies were then killed using chloroform vapors and overlaid with a top TY agar layer $\left(0.7 \%, \mathrm{w} / \mathrm{v}\right.$, soft agar) containing $10^{7}$ cells from one of 6 indicator strains (E. coli K12-Row, E. coli C6 (ф), E. coli 5 K, E. coli P400, E. coli S40 and Shigella sonnei 17$)$. The plates were subsequently incubated at $37^{\circ} \mathrm{C}$ for 24 hours and bacteriocin producers were identified.

\section{PCR detection of genes encoding bacteriocins}

Detection of the 24 colicin and 7 microcin genes was carried out using the method described by Šmajs et al. (2010) [21]. Briefly, genomic DNA was isolated using DNAzol reagent (Invitrogen, Carlsbad, CA, USA) according to the manufacturer's protocol. Template DNA was diluted 100 -fold in sterile distilled water. All producer strains were tested, in parallel, using the colony PCR method (one bacterial colony from each strain was resuspended in $100 \mu \mathrm{l}$ of sterile distilled water; then $1 \mu \mathrm{l}$ of this suspension was added to the PCR mix). PCR reactions were performed using the primers described by Šmajs et al. (2010) [21]; for colicins E1, L and microcin $\mathrm{M}$ additional primer pairs were used (Additional file 2: Table S2). The following protocol was used for PCR amplification: $94^{\circ} \mathrm{C}$ ( 2 minutes); $94^{\circ} \mathrm{C}$ (30 seconds), $60^{\circ} \mathrm{C}$ (30 seconds), $72^{\circ} \mathrm{C}$ ( 1 minute), 30 cycles; $72^{\circ} \mathrm{C}$ ( 7 minutes). For colony PCR, the initial step was 5 minutes. Microcins $\mathrm{H} 47$ and $\mathrm{M}$ are sensitive to chloroform vapors [19], therefore all 539 bacteriocin-nonproducing E. coli strains were investigated using PCR with specific $\mathrm{H} 47$ and $\mathrm{M}$ primers. PCR products of sequentially related bacteriocins (colicins E2-9, Ia-Ib, U-Y, 5-10) were verified using dideoxy terminator sequencing and amplification primers. Sequence analysis was carried out using Lasergene software (DNASTAR, Inc., Madison, WI, USA).

\section{Screening for genes encoding virulence factors}

All 1181 E. coli strains were screened for the presence of genes for 17 different virulence factors $(\alpha$-hly, afaI, aer, cnf1, sfa, pap, pCVD432, ial, lt, st, bfpA, eaeA, ipaH, $i u c C$, fimA, stx1, stx2 and ehly). The primer pair sequences, PCR product lengths and PCR protocols used, were previously described [48-55].

\section{Statistical analyses}

For statistical analysis of the incidence of bacteriocins and virulence factors, standard methods derived from the binomial distribution, including the two-tailed Fisher's exact test corrected using the Bonferroni correction, were used. STATISTICA software, version 8.0 (StatSoft, Tulsa, OK, USA), was used for calculations. Distribution of virulence factors and bacteriocin genes were determined using Correspondence Analysis (CA) and STATISTICA version 8.0.

\section{Availability of supporting data}

The data set of 294 colicin gene sequences supporting the results of the article has been deposited in the GenBank/EMBL/DDBJ under accession numbers AB92 3519 - AB923812.

\section{Additional files}

Additional file 1: Table S1 Distribution of virulence determinants and bacteriocin genes among $1181 \mathrm{E}$. coli strains isolated from human fecal microflora.

Additional file 2: Table S2 DNA Primers used for PCR detection of colicin and microcin encoding genes.

\section{Competing interests}

The authors declare that they have no competing interests.

\section{Authors' contributions}

DS designed the study and together with LM wrote the manuscript. LM, BS, $J B$ and LMik performed bacteriocin and virulence testing of E. coli strains. LM and SL analyzed the data. MV, AS and WW contributed to isolation and characterization of the bacterial strains and gathered data. All authors read and approved the final manuscript.

\section{Acknowledgments}

This work was supported by a grant from the Ministry of Health of the Czech Republic (NT13413-4/2012) to D.S.

\section{Author details}

'Department of Biology, Faculty of Medicine, Masaryk University, Kamenice 5 , Building A6, Brno 625 00, Czech Republic. ${ }^{2}$ Institute of Biostatistics and Analyses, Masaryk University, Kamenice 3, Building A1, Brno 625 00, Czech Republic. ${ }^{3}$ Department of Clinical Microbiology, University Hospital Brno, Jihlavská 20, Brno 625 00, Czech Republic. ${ }^{4}$ Department of Microbiology, Faculty of Medicine, Masaryk University and St. Anne's University Hospital, Pekařská 53, Brno 656 91, Czech Republic.

Received: 17 December 2013 Accepted: 22 April 2014

Published: 28 April 2014

\section{References}

1. Eckburg PB, Bik EM, Bernstein CN, Purdom E, Dethlefsen L, Sargent M, Gill $\mathrm{SR}$, Nelson KE, Relman DA: Diversity of the human intestinal microbial flora. Science 2005, 308:1635-1638.

2. Sonnenborn U, Greinwald R: Beziehungen zwischen Wirtororganismus und Darmflora. Stuttgart - New York: Schattauer; 1991

3. Guarner F, Malagelada J-R: Role of bacteria in experimental colitis. Best Pract Res Clin Gastroenterol 2003, 17:793-804.

4. Dobrindt U, Agerer F, Michaelis K, Janka A, Buchrieser C, Samuelson M, Svanborg C, Gottschalk G, Karch H, Hacker J: Analysis of genome plasticity in pathogenic and commensal Escherichia coli isolates by use of DNA arrays. J Bacteriol 2003, 185:1831-1840. 
5. Russo TA, Johnson JR: Proposal for a new inclusive designation for extraintestinal pathogenic isolates of Escherichia coli: ExPEC. J Infect Dis 2000, 181:1753-1754.

6. Finlay BB, Falkow S: Common themes in microbial pathogenicity revisited. Microbiol Mol Biol Rev 1997, 61:136-169.

7. Ochman H, Selander RK: Standard reference strains of Escherichia coli from natural populations. J Bacteriol 1984, 157:690-693.

8. Nataro JP, Kaper JB: Diarrheagenic Escherichia coli. Clin Microbiol Rev 1998, 11:142-201

9. Girón JA, Jones T, Millán-Velasco F, Castro-Muñoz E, Zárate L, Fry J, Frankel G, Moseley SL, Baudry B, Kaper JB: Diffuse-adhering Escherichia coli (DAEC) as a putative cause of diarrhea in Mayan children in Mexico. $J$ Infect Dis 1991, 163:507-513.

10. Nataro JP, Kaper JB, Robins-Browne R, Prado V, Vial P, Levine MM: Patterns of adherence of diarrheagenic Escherichia coli to HEp-2 cells. Pediatr Infect Dis $J$ 1987, 6:829-831.

11. Johnson JR, Murray AC, Gajewski A, Sullivan M, Snippes P, Kuskowski MA Smith KE: Isolation and molecular characterization of nalidixic acidresistant extraintestinal pathogenic Escherichia coli from retail chicken products. Antimicrob Agents Chemother 2003, 47:2161-2168.

12. Braun V, Pilsl H, Gross P: Colicins: structures, modes of action, transfer through membranes, and evolution. Arch Microbiol 1994, 161:199-206.

13. Gillor O, Nigro LM, Riley MA: Genetically engineered bacteriocins and their potential as the next generation of antimicrobials. Curr Pharm Des 2005, 11:1067-1075.

14. Moreno F, San Millán JL, Hernández-Chico C, Kolter R: Microcins. Biotechnology 1995, 28:307-321.

15. Šmarda J, Šmajs D: Colicins-exocellular lethal proteins of Escherichia coli. Folia Microbiol (Praha) 1998, 43:563-582.

16. Šmajs D, Weinstock GM: Genetic organization of plasmid ColJs, encoding colicin Js activity, immunity, and release genes. J Bacteriol 2001, 183:3949-3957.

17. Šmajs D, Weinstock GM: The iron- and temperature-regulated cjrBC genes of Shigella and enteroinvasive Escherichia coli strains code for colicin Js uptake. J Bacteriol 2001, 183:3958-3966

18. Riley MA, Wertz JE: Bacteriocin diversity: ecological and evolutionary perspectives. Biochimie 2002, 84:357-364.

19. Patzer SI, Baquero MR, Bravo D, Moreno F, Hantke K: The colicin G, H and X determinants encode microcins $\mathrm{M}$ and $\mathrm{H} 47$, which might utilize the catecholate siderophore receptors FepA, Cir, Fiu and IroN. Microbiology (Reading, Engl) 2003, 149(9):2557-2570.

20. Azpiroz MF, Poey ME, Laviña M: Microcins and urovirulence in Escherichia coli. Microb Pathog 2009, 47:274-280

21. Šmajs D, Micenková L, Šmarda J, Vrba M, Ševčíková A, Vališová Z, Woznicová $\checkmark$ : Bacteriocin synthesis in uropathogenic and commensal Escherichia coli: colicin E1 is a potential virulence factor. BMC Microbio/ 2010, 10:288

22. Budič M, Rijavec M, Petkovšek Z, Zgur-Bertok D: Escherichia coli bacteriocins: antimicrobial efficacy and prevalence among isolates from patients with bacteraemia. PLOS ONE 2011, 6:e28769.

23. Petkovšek Z, Zgur-Bertok D, Starcic Erjavec M: Colicin insensitivity correlates with a higher prevalence of extraintestinal virulence factors among Escherichia coli isolates from skin and soft-tissue infections. J Med Microbiol 2012, 61(Pt 6):762-5.

24. Šmajs D, Karpathy SE, Šmarda J, Weinstock GM: Colicins produced by the Escherichia fergusonii strains closely resemble colicins encoded by Escherichia coli. FEMS Microbiol Lett 2002, 208:259-262.

25. Chumchalová J, Šmarda J: Human tumor cells are selectively inhibited by colicins. Folia Microbiol (Praha) 2003, 48:111-115.

26. Gordon DM, O'Brien CL: Bacteriocin diversity and the frequency of multiple bacteriocin production in Escherichia coli. Microbiology (Reading, Engl) 2006, 152(11):3239-3244.

27. Abraham S, Chapman TA, Zhang R, Chin J, Mabbett AN, Totsika M: Molecular characterization of Escherichia coli strains that cause symptomatic and asymptomatic urinary tract infections. J Clin Microbiol 2012, 50:1027-30.

28. Gordon DM, Stern SE, Collignon PJ: The influence of the age and sex of human hosts on the distribution of Escherichia coli ECOR groups and virulence traits. Microbiology 2005, 151:15-23.

29. Riley MA, Gordon DM: A survey of Col plasmids in natural isolates of Escherichia coli and an investigation into the stability of Col-plasmid lineages. J Gen Microbio/ 1992, 138:1345-1352.
30. Achtman M, Mercer A, Kusecek B, Pohl A, Heuzenroeder M, Aaronson W Sutton A, Silver RP: Six widespread bacterial clones among Escherichia coli K1 isolates. Infect Immun 1983, 39:315-335.

31. Šmajs D, Čejková D, Micenková L, Lima-Bittencourt Cl, Chartone-Souza E, Šmarda J, Nascimento AMA: Human Escherichia coli strains of different geographical and time source: bacteriocin types and their gene sequences are population-specific. Environ Microbiol Rep 2012, 4:459-466.

32. Šmarda J, Obdržálek V: Incidence of colicinogenic strains among human Escherichia coli. J Basic Microbio/ 2001, 41:367-74.

33. Connell I, Agace W, Klemm P, Schembri M, Marild S, Svanborg C: Type 1 fimbrial expression enhances Escherichia coli virulence for the urinary tract. Proc Natl Acad Sci U S A 1996, 93:9827-9832.

34. Hagberg L, Jodal U, Korhonen TK, Lidin-Janson G, Lindberg U, Edén CS: Adhesion, hemagglutination, and virulence of Escherichia coli causing urinary tract infections. Infect Immun 1981, 31:564-570.

35. Leffler H, Svanborg-Eden C: Glycolipid receptors for uropathogenic Escherichia coli on human erythrocytes and uroepithelial cells. Infect Immun 1981, 34:920-929.

36. Edén CS, Freter R, Hagberg L, Hull R, Hull S, Leffler H, Schoolnik G: Inhibition of experimental ascending urinary tract infection by an epithelial cell-surface receptor analogue. Nature 1982, 298:560-562.

37. Väisänen-Rhen V, Elo J, Väisänen E, Siitonen A, Orskov I, Orskov F, Svenson SB, Mäkelä PH, Korhonen TK: P-fimbriated clones among uropathogenic Escherichia coli strains. Infect Immun 1984, 43:149-155.

38. Johnson JR: Virulence factors in Escherichia coli urinary tract infection Clin Microbiol Rev 1991, 4:80-128.

39. Bergsten G, Wullt B, Svanborg C: Escherichia coli, fimbriae, bacterial persistence and host response induction in the human urinary tract. Int J Med Microbiol 2005, 295:487-502.

40. Pilsl H, Šmajs D, Braun V: Characterization of colicin S4 and its receptor, OmpW, a minor protein of the Escherichia coli outer membrane. J Bacteriol 1999, 181:3578-3581.

41. Wold AE, Caugant DA, Lidin-Janson G, de Man P, Svanborg C: Resident colonic Escherichia coli strains frequently display uropathogenic characteristics. J Infect Dis 1992, 165:46-52.

42. Nowrouzian F, Adlerberth I, Wold AE: P fimbriae, capsule and aerobactin characterize colonic resident Escherichia coli. Epidemiol Infect 2001, 126:11-18.

43. Nowrouzian F, Wold AE, Adlerberth I: P fimbriae and aerobactin as intestinal colonization factors for Escherichia coli in Pakistani infants. Epidemiol Infect 2001, 126:19-23.

44. Nowrouzian F, Hesselmar B, Saalman R, Strannegard I-L, Aberg N, Wold AE Adlerberth I: Escherichia coli in infants' intestinal microflora: colonization rate, strain turnover, and virulence gene carriage. Pediatr Res 2003, 54:8-14

45. Doye A, Mettouchi A, Bossis G, Clément R, Buisson-Touati C, Flatau G, Gagnoux L, Piechaczyk M, Boquet P, Lemichez E: CNF1 exploits the ubiquitin-proteasome machinery to restrict Rho GTPase activation for bacterial host cell invasion. Cell 2002, 111:553-564.

46. Wiles TJ, Kulesus RR, Mulvey MA: Origins and virulence mechanisms of uropathogenic Escherichia coli. Exp Mol Pathol 2008, 85:11-9.

47. Gao Q, Wang X, Xu H, Xu Y, Ling J, Zhang D, Gao S, Liu X: Roles of iron acquisition systems in virulence of extraintestinal pathogenic Escherichia coli: salmochelin and aerobactin contribute more to virulence than heme in a chicken infection model. BMC Microbiol 2012, 12:143.

48. Martínez JL, Herrero M, de Lorenzo V: The organization of intercistronic regions of the aerobactin operon of pColV-K30 may account for the differential expression of the iucABCD iutA genes. J Mol Biol 1994, 238:288-293.

49. Schmidt $H$, Knop C, Franke S, Aleksic S, Heesemann J, Karch $H$ Development of PCR for screening of enteroaggregative Escherichia coli. J Clin Microbiol 1995, 33:701-705.

50. Yamamoto S, Terai A, Yuri K, Kurazono H, Takeda Y, Yoshida O: Detection of urovirulence factors in Escherichia coli by multiplex polymerase chain reaction. FEMS Immunol Med Microbiol 1995, 12:85-90.

51. Kuhnert P, Hacker J, Mühldorfer I, Burnens AP, Nicolet J, Frey J: Detection system for Escherichia coli-specific virulence genes: absence of virulence determinants in B and C strains. Appl Environ Microbiol 1997, 63:703-709.

52. Paton AW, Paton JC: Detection and characterization of Shiga toxigenic Escherichia coli by using multiplex PCR assays for stx1, stx2, eaeA, 
enterohemorrhagic E. coli hlyA, rfbO111, and rfbO157. J Clin Microbiol 1998, 36:598-602.

53. Paciorek J: Virulence properties of Escherichia coli faecal strains isolated in Poland from healthy children and strains belonging to serogroups 018, 026, 044, 086, 0126 and 0127 isolated from children with diarrhoea. J Med Microbiol 2002, 51:548-556.

54. López-Saucedo C, Cerna JF, Villegas-Sepulveda N, Thompson R, Velazquez FR, Torres J, Tarr PI, Estrada-García T: Single multiplex polymerase chain reaction to detect diverse loci associated with diarrheagenic Escherichia coli. Emerging Infect Dis 2003, 9:127-131.

55. Bírošová E, Siegfried L, Kmetová M, Makara A, Ostró A, Gresová A, Urdzík P, Liptáková A, Molokácová M, Bártl R, Valanský L: Detection of virulence factors in alpha-haemolytic Escherichia coli strains isolated from various clinical materials. Clin Microbiol Infect 2004, 10:569-573.

doi:10.1186/1471-2180-14-109

Cite this article as: Micenková et al:: Bacteriocin-encoding genes and

EXPEC virulence determinants are associated in human fecal Escherichia coli strains. BMC Microbiology 2014 14:109.

\section{Submit your next manuscript to BioMed Central and take full advantage of:}

- Convenient online submission

- Thorough peer review

- No space constraints or color figure charges

- Immediate publication on acceptance

- Inclusion in PubMed, CAS, Scopus and Google Scholar

- Research which is freely available for redistribution 